\title{
Biosorption of mercury (II) from aqueous solution onto biomass of Aspergillus niger
}

\section{Bioadsorción de mercurio (II) en solución acuosa por la biomasa de Aspergillus niger}

Ismael Acosta Rodríguez ${ }^{*}$, Nancy Cecilia Pacheco-Castillo ${ }^{1}$, Juan Fernando CárdenasGonzález², María de Guadalupe Moctezuma Zarate¹, Víctor Manuel Martínez-Juárez ${ }^{3}$, Adriana Rodríguez-Pérez ${ }^{2}$

${ }^{1}$ Laboratorio de Micología Experimental. Facultad de Ciencias Químicas. Universidad Autónoma de San Luis Potosí, '2Universidad Autónoma de San Luis Potosí, Unidad Académica Multidisciplinaria Zona Media. Carretera Río Verde san Ciro Km 4.5. Colonia Puente del Carmen, C.P. 79617. Río Verde, San Luis Potosí, México. ${ }^{3}$ Área Académica de Medicina Veterinaria y Zootecnia. Instituto de Ciencias Agropecuarias. Universidad Autónoma del Estado de Hidalgo, México.

*Corresponding author.

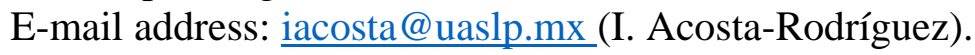

Article history:

Received: 29 December 2017 / Received in revised form: 14 April 2018 / Accepted: 4 May 2018 / Published online: 1 July 2018.

https://doi.org/10.29267/mxjb.2018.3.3.15

\begin{abstract}
Mercury (II) removal capacity in aqueous solution by Aspergillus niger biomass was analyzed by the atomic absorption spectrometry method. The fungus grew in $2000 \mathrm{ppm}$ of the metal (20.3\%). Biosorption was evaluated at different $\mathrm{pH}(3.5,4.5$, and 5.5) at different times. In addition, the effect of temperature in the range of $28^{\circ} \mathrm{C}$ to $45^{\circ} \mathrm{C}$ and removal at different initial concentrations of $\mathrm{Hg}$ (II) from 100 to $500 \mathrm{mg} / \mathrm{L}$ were also studied. The highest biosorption $(83.2 \%$ with $100 \mathrm{mg} / \mathrm{L}$ of the metal, and $1 \mathrm{~g}$ of biomass) was $24 \mathrm{~h}$ at $\mathrm{pH}$ of 5.5 and $28^{\circ} \mathrm{C}$. With regard to temperature, the highest removal was to $28^{\circ} \mathrm{C}$, with an 83.2\% removal at $24 \mathrm{~h}$, and at higher biomass concentrations, the removal was most efficient (100\% in $12 \mathrm{~h}$ with $5 \mathrm{~g}$ of biomass). Fungal biomass showed good removal capacity of the metal in situ, 69\% removal in contaminated water, after 7 days of incubation and $5 \mathrm{~g}$ of biomass $(100 \mathrm{~mL}$ water), so it can be used to remove industrial wastewater.
\end{abstract}


Keywords: Aspergillus niger, biomass, mercury (II), removal.

\section{RESUMEN}

Se analizó la capacidad de remoción de mercurio (II) en solución acuosa por la biomasa de Aspergillus niger por el método de espectrometría de absorción atómica. El hongo crece hasta $2000 \mathrm{ppm}$ del metal (20.3\%). Se evaluó la bioadsorción a diferentes valores de $\mathrm{pH}$ $(3.5,4.5$ y 5.5$)$ a diferentes tiempos. También se estudió el efecto de la temperatura en el intervalo de $28^{\circ} \mathrm{C}$ hasta $45^{\circ} \mathrm{C}$ y la remoción a diferentes concentraciones iniciales de $\mathrm{Hg}$ (II) de 100 a $500 \mathrm{mg} / \mathrm{L}$. La mayor bioadsorción $(83.2 \%$ con $100 \mathrm{mg} / \mathrm{L}$ del metal y $1 \mathrm{~g}$ de biomasa) fue a las $24 \mathrm{~h}$, a $\mathrm{pH}$ de 5.5 y $28^{\circ} \mathrm{C}$. Con respecto a la temperatura, la más alta remoción fue a $\operatorname{los} 28^{\circ} \mathrm{C}$, con un $83.2 \%$ de remoción a las $24 \mathrm{~h}$, y a mayores concentraciones de biomasa, la remoción fue más eficiente (100\%, 12 h y 5 g de biomasa). La biomasa natural mostró una excelente capacidad de remoción del metal in situ, 69\% de remoción en aguas contaminadas, a los 7 días de incubación y 5 g de la biomasa $(100 \mathrm{~mL}$ de agua), por lo que se puede utilizar para eliminarlo de aguas residuales industriales.

Palabras clave: Aspergillus niger, biomasa, mercurio (VI), remoción.

\section{INTRODUCTION}

At present, there is a great concern in the world, due to the considerable increase in the levels of contamination of industrial effluents by heavy metals such as chromium, nickel, cadmium, lead and mercury (Stefanescu et al., 2017). These toxic substances tend to persist indefinitely in the environment, compromising the well-being and balance not only of the fauna and flora existing in the ecosystem but also the health of people living in the surrounding communities, through their accumulation and entry into the food chain (Cabral et al., 2014). Among the various effects produced by heavy metals in plants are necrosis at the tips of leaves, inhibition of root growth, and at worst the total death of the plant. In humans, heavy metals can become very toxic when introduced into the organism. At high concentrations, these can cause: skin rashes, stomach upset (ulcers), respiratory problems, weakening of the immune system, damage to the kidneys and liver, hypertension, alteration of genetic material, cancer, neurological disorders and even death (Nava Ruiz and Mendez Armenta, 2011). The World Health Organization (WHO) established that the maximum concentration of heavy metal ions in water should be in the range of 0.01-1 ppm (WHO, 2003), however, concentrations of heavy metal ions up to $450 \mathrm{ppm}$ have been found in effluents (Srivastava \& Anil Dwivedi, 2015). Among the main industrial sectors that are sources of contamination of heavy metals are mining, cement industry, dyes, tanning, electroplating, steel production, photographic material, corrosion paints, energy production, textile fabrication, wood preservation, aluminum anodizing, water cooling and others (Abass et al., 2014; Stefanescu et al., 2017). In Cedral, San Luis Potosí, México the Hg (II) contamination in areas of historical silver amalgamation was evaluate. The total concentrations of $\mathrm{Hg}$ in mining residues varied between 8 and $548 \mathrm{mg} / \mathrm{kg}$, while in soils the concentrations were in a range of between 1 and $116 \mathrm{mg} / \mathrm{kg}$. It was found that $80 \%$ of the soil samples analyzed exceeded the maximum permissible limit of $\mathrm{Hg}$ for land for 
residential use established in Mexican regulations (Leura Vicencio et. al., 2017). Too, Giangrosso et. al., (2016), studied the hair mercury levels detection in fisherman from Sicily (Italy).

The environmental impact generated by these toxic substances has led the scientific community to develop different methods for the treatment of industrial effluents contaminated with these substances, among which are: precipitation, oxidation-reduction, exchange ionic, filtration, electrochemical treatment, membrane technologies and recovery by evaporation. However, these methods have been quite costly and inefficient, especially when the metals concentration is very low, as well as the formation, disposal and storage of sludge and wastes, originated during the processes, which becomes a major problem to solve (Tejada-Tovar et al., 2015; Caviedes Rubio et al., 2015). Therefore, arise emerging technologies such as biosorption, the process of attracting various chemical species by biomass (live or dead), by physicochemical mechanisms as adsorption or ion exchange (Tejada Tovar et al., 2015). Recently, varieties of low cost materials have been studied for their ability to removal $\mathrm{Hg}$ (II) from aqueous solution and promising results are shown. Among these low cost adsorbents are dead microorganisms, clay minerals, agricultural wastes, industrial wastes and various other low cost materials (Alimohammadi et al., 2017; Duygu Ozsoy, 2010; Hoque and Fritscher, 2016; Martínez-Juárez et al., 2012; Shekhawat et al., 2017; Stefanescu et al., 2017; Tejada Tovar et al., 2015). Thus, there is a need to develop or find innovative low cost adsorbents with an affinity towards metal ions for the removal of $\mathrm{Hg}$ (II) from aqueous solution, which leads to high adsorption capacity (Caviedes Rubio et al., 2015). The objective of this study was to analyze biosorption of $\mathrm{Hg}$ (II) by Aspergillus niger biomass, which also remove other metals such as chromium (VI), and arsenic (III, and V).

\section{MATERIALS AND METHODS}

\subsection{Biosorbent used and resistant to mercury test}

It worked with a strain of A. niger that grows in 200 ppm of As (III) (Santos et al., 2017) and that was isolated from the environment from a zone adjacent to the Faculty of Chemical Sciences of the UASLP, San Luis Potosí, S.L.P., Mexico; and was identified based on its morphological characteristics, both macro and microscopic (López Martínez et al., 2004). The fungal strain was routinely maintained on potato dextrose agar. For the obtain the biomass, $1 \times 10^{6}$ spores/ $\mathrm{mL}$ of the fungus were inoculated in $1 \mathrm{~L}$ Erlenmeyer flasks, containing $600 \mathrm{~mL}$ of thioglicolate broth, incubating for 5 days at $28^{\circ} \mathrm{C}$ and $100 \mathrm{rpm}$. Later, the biomass was obtained by filtration, washed with $200 \mathrm{~mL}$ of trideionized water, and was dried at $80^{\circ} \mathrm{C}$, for 12 hours in bacteriological oven. The product was ground in blender and stored in amber vials until use.

Mercury-resistant tests of the isolated strain, filamentous fungus A. niger, were performed on liquid LMM (Lee's medium minimum) containing the appropriate nutritional requirements and different concentrations of $\mathrm{Hg}$ (II) (as mercury chloride), and the dry weight was determined. 


\subsection{Biosorption studies and determination of divalent mercury}

They prepared a series of solutions of mercury of $100 \mathrm{mg} / \mathrm{L}, \mathrm{pH}$ was adjusted with sulfuric acid $1 \mathrm{M}$ and the quantity of biomass added to each flask was of $1 \mathrm{~g} / 100 \mathrm{~mL}$ for the mercury's solution. They were taken samples at different times, the biomass is eliminated for centrifugation $(3000 \mathrm{rpm} / 5 \mathrm{~min})$ and the supernatant was analyzed to define the ion metal concentration. The concentration of mercury ions in solution was determined by Atomic Absorption Spectrometry for generation of Hydrides (Atomic Absorption Spectrometer Varian, model Spectra AA- 20), according to the procedure indicated by the Official Mexican Standard (SSA, 1994). The experiments were performed a minimum of 3 times and in triplicate.

\section{RESULTS}

The cells of the fungal strain grew on LMM supplemented with $2 \mathrm{~g} / \mathrm{L}$ of $\mathrm{Hg}$ (II); about $20.3 \%$ of growth relative to control $(85.4 \mathrm{mg}$ of dry weight without metal) was obtained (Fig. 1) and, therefore, probably is resistant to the metal. We do not know why, however, at 600 p.m. there is more growth so we can say that there is more resistance.

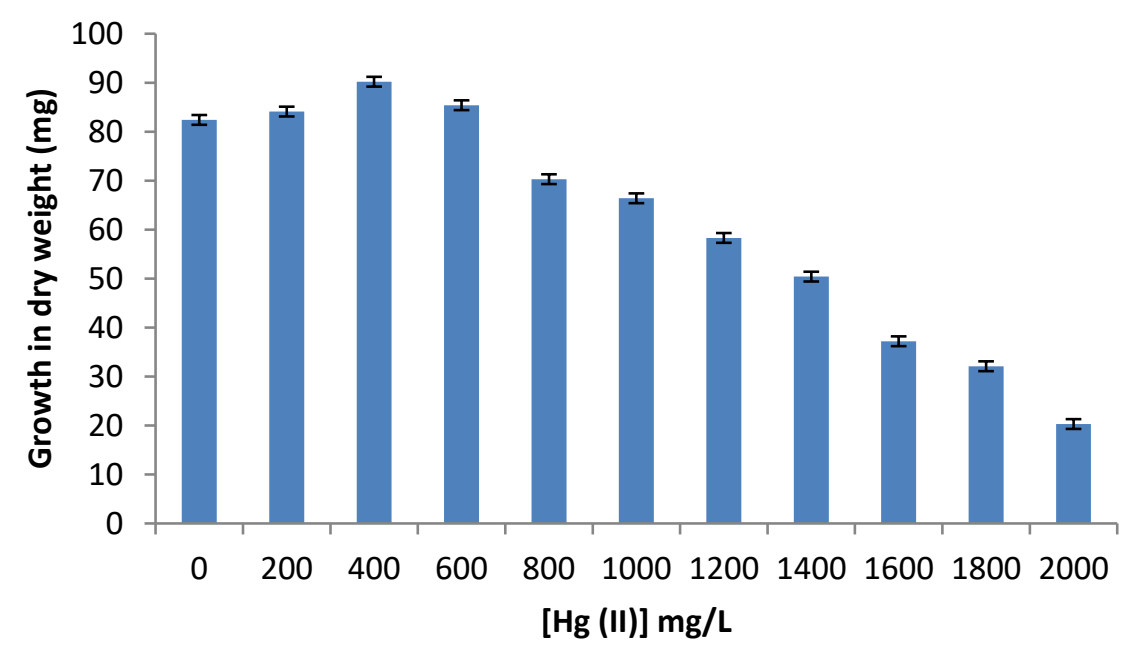

Fig. 1. Final dry weight of A. niger with different initial concentrations of $\mathrm{Hg}$ (II), $1 \times 10^{6}$ spores $/ \mathrm{mL}, 28^{\circ} \mathrm{C}, 7$ days of incubation, and $100 \mathrm{rpm}$.

The optimum time and $\mathrm{pH}$ for $\mathrm{Hg}$ (II) removal for A. niger biomass was $24 \mathrm{~h}$ and $\mathrm{pH} 5.5$, at constant values of biosorbent dosage $(1 \mathrm{~g} / 100 \mathrm{~mL})$, with an initial metal concentration (100 $\mathrm{mg} / \mathrm{L}$ ), and temperature of $28^{\circ} \mathrm{C}$ (Fig. 2). Adsorption efficiency of $\mathrm{Hg}$ (II) was observe a maximum at $\mathrm{pH} 5.5$ with the biomass analyzed. As the initial $\mathrm{pH}$ values decreased from 5.5 to 3.5 , the removal efficiencies of $\mathrm{Hg}$ (II) with the biomass decreased from $83.2 \%$ to $36.1 \%$, respectively (Fig. 2). 


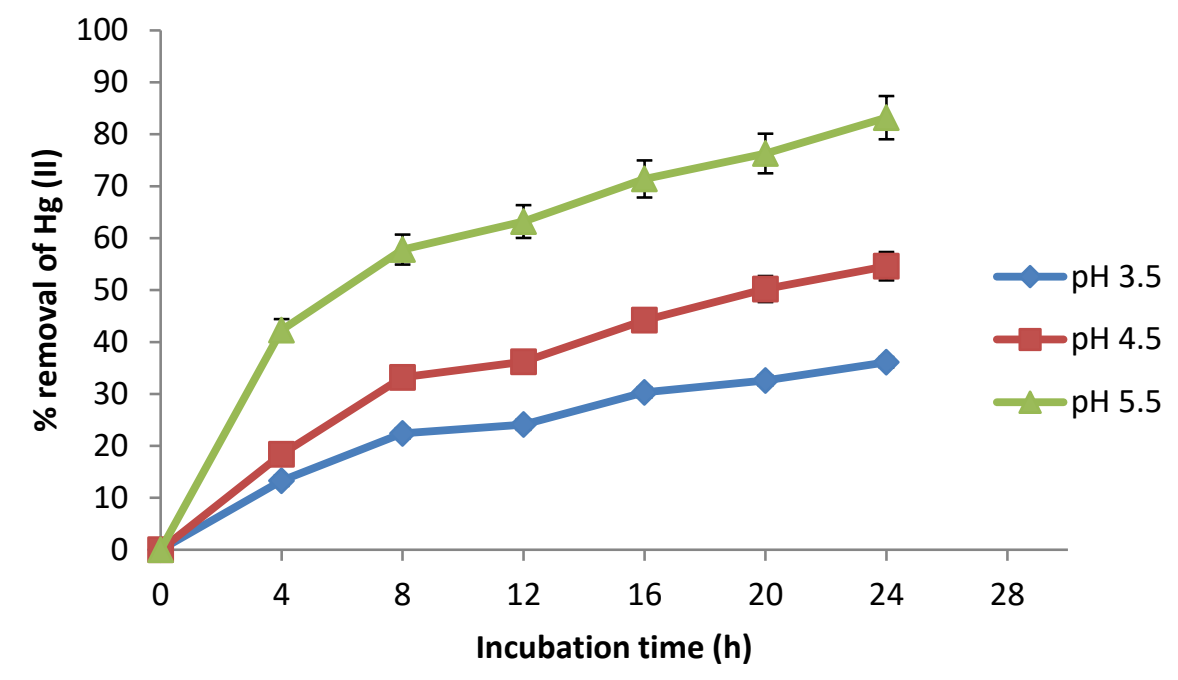

Fig. 2. Effect of incubation time and $\mathrm{pH}$ on mercury (II) removal by the biomass of $A$. niger. $100 \mathrm{mg} / \mathrm{L} \mathrm{Hg}(\mathrm{II}), 100 \mathrm{rpm}, 28^{\circ} \mathrm{C}, 1 \mathrm{~g}$ of biomass.

Temperature was found to be a critical parameter in the bioadsorption of $\mathrm{Hg}$ (II) (Fig. 3). The higher removal was observed at $28^{\circ} \mathrm{C}$ with $24 \mathrm{~h}$ of incubation.

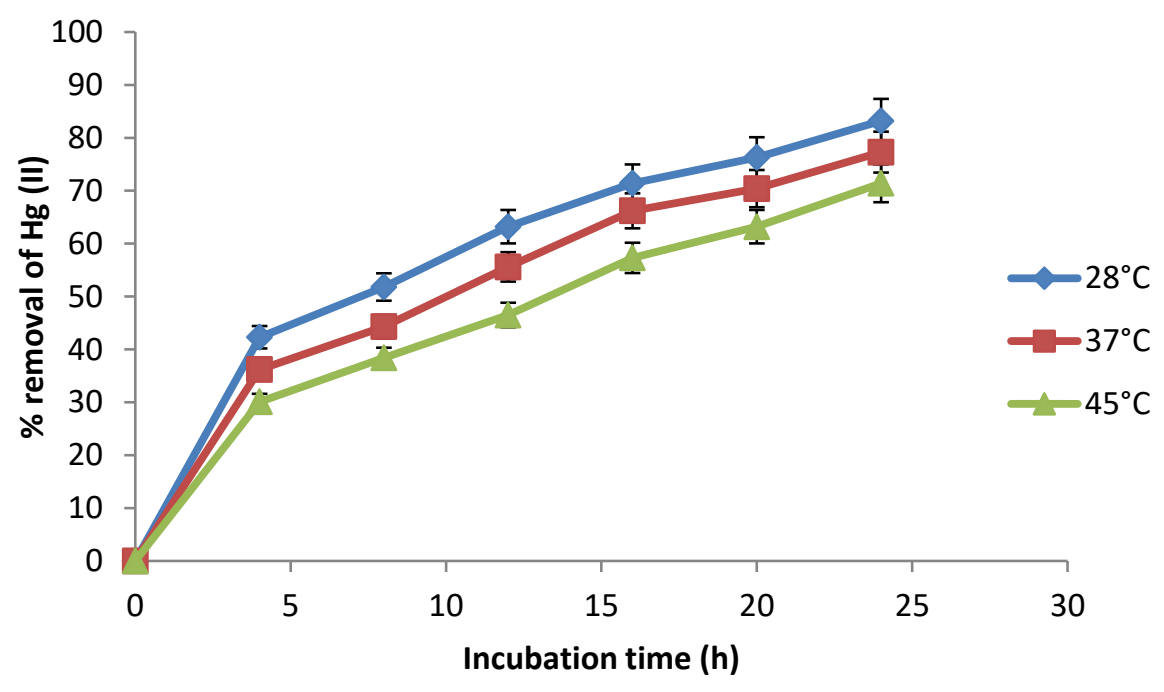

Fig. 3. Effect of temperature on mercury (II) removal by the biomass of A. niger. $100 \mathrm{mg} / \mathrm{L}$ $\mathrm{Hg}$ (II), $100 \mathrm{rpm}, 28^{\circ} \mathrm{C} .1 \mathrm{~g}$ of biomass.

Otherwise, at low metal concentrations $(100 \mathrm{mg} / \mathrm{L})$, we observe the best results for removal, with the biomass analyzed, at $28^{\circ} \mathrm{C}$, respectively (Fig. 4). 


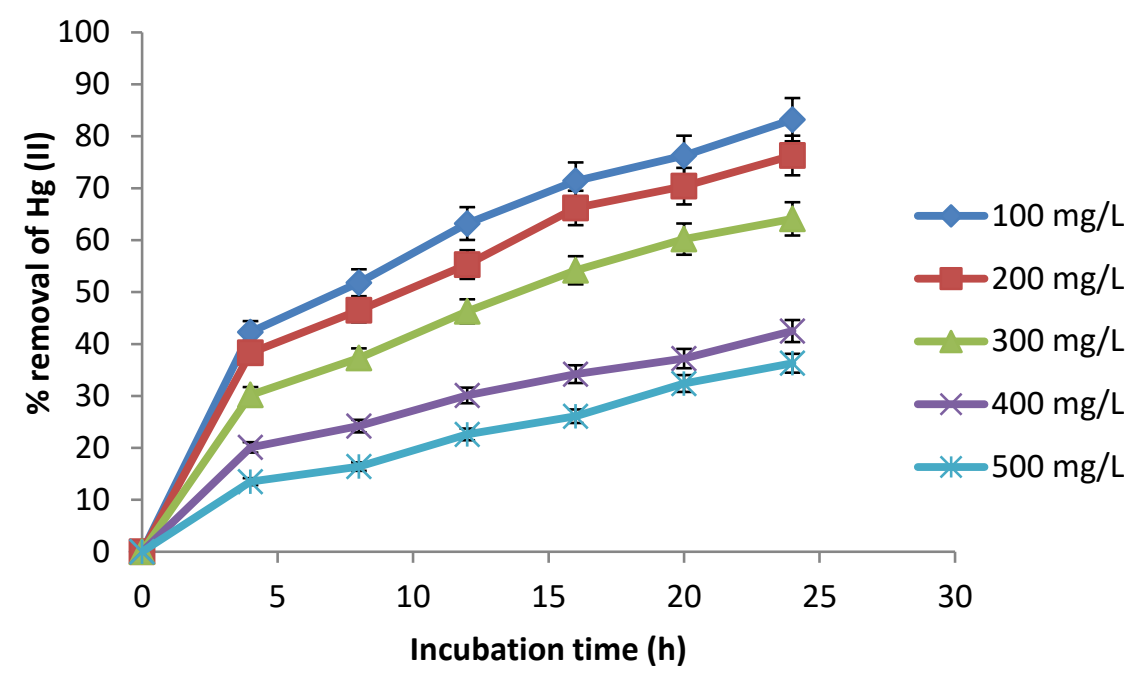

Fig. 4. Effect of initial concentration of metal on mercury (II) removal by the biomass of $A$. niger. $100 \mathrm{rpm}, 28^{\circ} \mathrm{C} .1 \mathrm{~g}$ of biomass.

The influence of biomass concentration on the removal capacity of $\mathrm{Hg}$ (II) is depict in Fig. 5. If we increase, the amount of biomass it also increases the removal of the metal in solution, with more biosorption sites of the same, because the amount of added biosorbent determines the number of binding sites available for metal biosorption (Cervantes et al., 2001).

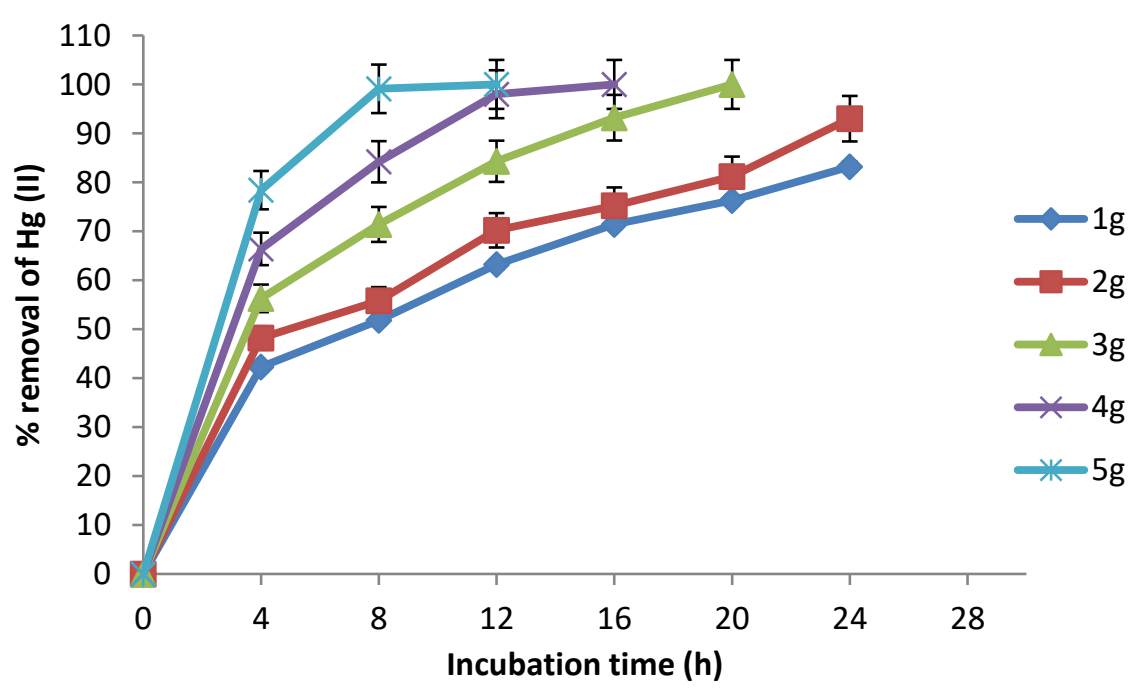

Fig. 5. Effect of biomass concentration on the removal of $100 \mathrm{mg} / \mathrm{L}$ of mercury (II) by the biomass of $A$. niger. $100 \mathrm{rpm}, 28^{\circ} \mathrm{C}$.

Finally, we adapted a water-phase bioremediation assay to explore possible usefulness of this biomass for eliminating $\mathrm{Hg}$ (II) from industrial wastes, the biomass (5 g), was incubate 
with non-sterilized contaminated water containing $183 \mathrm{mg} \mathrm{Hg}$ (II)/L. It was observe that in 7 days of incubation with the biomass, the $\mathrm{Hg}$ (II) concentration of water samples decrease $69 \%$ (Fig. 6).

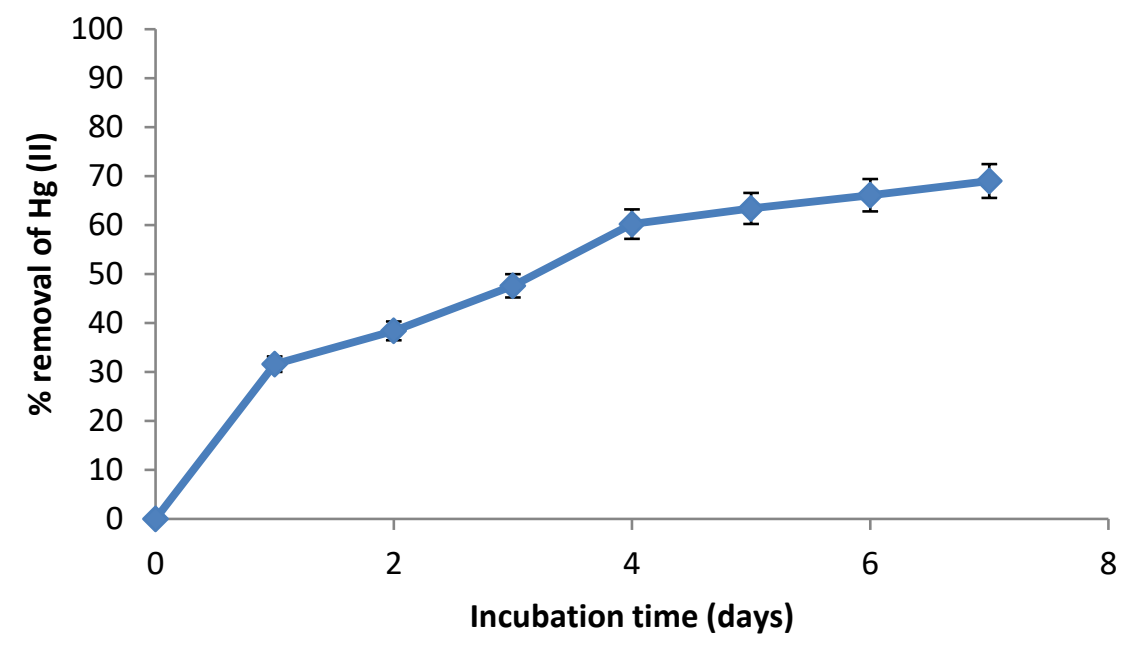

Fig. 6. Removal of $\mathrm{Hg}$ (II) in industrial wastes incubated with $5 \mathrm{~g}$ of biomass. $28^{\circ} \mathrm{C}, 100$ rpm, $100 \mathrm{~mL}$ of contaminated water, (183 $\mathrm{mg} \mathrm{Hg}$ (II)/L.

The adsorption capacities of $\mathrm{Cr}$ (VI) with different biosorbents are showed in Table 1 .

Table 1. Comparison of adsorption capacities of $\mathrm{Cr}(\mathrm{VI})$ with other biosorbents.

\begin{tabular}{|c|c|c|c|}
\hline Adsorbent & $\mathrm{pH}$ & $\begin{array}{l}\text { Adsorption capacity } \\
\mathrm{mg} / \mathrm{g}\end{array}$ & Reference \\
\hline Aspergillus niger & 5.2 & 3.2 & Karunasagar, et. al., 2003 \\
\hline Aspergillus versicolor & $5.0-6.0$ & 75.6 & Das et. al., 2007 \\
\hline $\begin{array}{l}\text { Different fungal } \\
\text { biomasses }\end{array}$ & 5.5 & $78.3-95.3$ & $\begin{array}{l}\text { Martínez-Juárez et. al., } \\
2012\end{array}$ \\
\hline Eucaliptus leaves & $5.0-6.0$ & 129.87 & Alimahammadi et. al., 2017 \\
\hline Impregnated chitosan & 3.0 & 43.3 & Shekawat et. al., 2017 \\
\hline $\begin{array}{l}\text { Phanerochaete } \\
\text { chrysosporium }\end{array}$ & 6.0 & 72.46 & Bashardoost et. al., 2010 \\
\hline Pleurotus sapidus & 6.0 & 207.89 & Yalcinkaya et. al., 2002 \\
\hline Rhizopus oligosporus & 6.0 & 33.33 & Duygu Ozsoy, 2010 \\
\hline Silica gel modified & $3.0-7.0$ & $0.20 *$ & Chaves et. al., 2011 \\
\hline Aspergillus niger & 5.5 & 83.2 & Present work \\
\hline
\end{tabular}




\section{DISCUSSION}

The fungal strain grew about $20.3 \%$ with $2 \mathrm{~g} / \mathrm{L}$ of $\mathrm{Hg}$ (II). Different microorganisms that are $\mathrm{Hg}$ (II) resistant have been isolated from different contaminated sites: Giovanella et. al., 2017) reported the bacteria: Pseudomonas putida C50A, Pseudomonas sp. B50D, Alcaligenes faecalis $\mathrm{U} 21$ and Brevundimonas sp.U22, which were isolated from metal contaminated residues and effluents, and they growth with $10 \mu \mathrm{M}$ of Hg; Mahbub et. al., (2016) isolated Sphingobium SA2, a highly mercury resistant bacterial strain from contaminated soil, with estimated $\mathrm{EC}_{50}$ values of $4.5 \mathrm{mg} / \mathrm{L}$ and $44.15 \mathrm{mg} / \mathrm{L}$ and MIC values of $5.1 \mathrm{mg} / \mathrm{L}$ and $48.48 \mathrm{mg} / \mathrm{L}$; Koushalshahi et. al., (2012), reported the isolation of Streptomyces from marine sediments in different regions of the Caspian Sea, resistant to 20 and $40 \mathrm{mg} / \mathrm{L}$ of $\mathrm{Hg}$. However, the mechanism of tolerance in this strain of A. niger fungus is not investigated.

On the other hand, among the most important environmental problems involving water and soil contamination of the country, is the direct dumping of heavy metals highly pollutants, which constitutes a danger to balance and natural functioning of aquatic ecosystems. One of these metals is mercury, which is used in artisan gold extraction and purification processes. Bioadsorption, to through the use of microorganisms and agroindustrial waste, has proven to be an alternative for the treatment of aquatic matrices contaminated by metals, is a clean technology, efficient and economical for environmental remediation processes. The main factors associated with the process of adsorption of $\mathrm{Hg}$ (II) by fungal biomass of $A$, niger, established that this biomaterial has a high potential in the removal of this metal, achieving a maximum removal of $83.2 \%(100 \mathrm{mg} / \mathrm{L}$ of the metal, and $1 \mathrm{~g}$ of biomass) at $24 \mathrm{~h}, \mathrm{pH}$ of 5.5 and $28^{\circ} \mathrm{C}$. The experimental evidence shows a strong effect of the experimental conditions. Maximum biosorption capacity values showed that this biosorbent used are very effective in recovery or removal of mercury ion from aquatic systems, like to others biosorbents (Table 1).

Finally, it was observing that in 7 days of incubation with the fungal biomass, the $\mathrm{Hg}$ (II) concentration of wastewater samples decrease $69 \%$. In the literature was reported the ability of the ethylhexadecyldimethyl ammonium bromide impregnated chitosan for removal of cadmium and mercury (Shekhawat et. al., 2017). Two different synthetic effluents containing Cd (II) in first while $\mathrm{Hg}$ (II) in second were prepared having similar composition to that of the real effluents and adsorption efficiency was determined for these metal ions. The results show a removal of $86.4 \%$, and $73.8 \%$, for $\mathrm{Cd}$ (II) and $\mathrm{Hg}$ (II), respectively (Shekhawat et. al., 2017). The widespread presence of biogenic selenium nanoparticles and goethite could significantly removal (81.2\%) mercury of contaminated groundwater (Wang et. al., 2018). The removal of $99 \%$ of the metal from water within 10$48 \mathrm{~h}$ after initial exposure to $\mathrm{Hg}$ (II), from Munich groundwater, with a new mercuryaccumulating Mucor hiemalis strain EH8 (Hoque and Fritscher, 2016). These results suggest their potential applicability for the remediation of $\mathrm{Hg}$ (II) from polluted water and soils in the fields. Otherwise, in mercury detoxification process, work is still necessary to illustrate the distribution and diversity of the microbial communities under heavy metals stress in order to employ them for the bioremediation of these toxic pollutants, singly or in combination for greater efficiency. Moreover, some mercury biosorbent fungi cannot only detoxify mercury but also remove other metals such as chromium (VI), and arsenic (III, and V) (Acosta-Rodríguez et. al., 2017; Santos et. al., 2017). 
In conclusion, the biomass analyzed, showed a good capacity of biosorption of $100 \mathrm{mg} / \mathrm{L}$ $\mathrm{Hg}$ (II) in solution at $24 \mathrm{~h}$ of incubation, at $28^{\circ} \mathrm{C}, 100 \mathrm{rpm}$ with $1 \mathrm{~g}$ of biomass, besides this removal the metal in situ (7 days of incubation, $5 \mathrm{~g}$ of biomass), in water contaminated.

\section{CONFLICT OF INTEREST}

The authors have no conflict of interest to declare

\section{REFERENCES}

Abbas, S.H., Ismail, I.M., Mostafa, T.M. \& Sulaymon, A.H. 2014. Biosorption of Heavy Metals: A Review. Journal of Chemical Science and Technology. 3(4): 74-102.

Acosta-Rodríguez, I., Cárdenas-González, J.F., Moctezuma-Zárate, M.G., Rodríguez Pérez, A. \& Martínez-Juárez, V.M. 2017. Hexavalent Chromium (VI) Removal by Aspergillus niger. In: "Metal-microbe interactions and bioremediation: Principles and applications for toxic metals". Editor: Surajis Das. CRS Press Book. Taylor Francis. Chapter 42, pp. 673688. ISBN: 9781498762434 (ebook).

Alimohammadi, M., Saeedi, Z., Akbarpour, B., Rasoulzadeh, H., Yetilmezsoy, K., AlGhouti, M.A., Khraisheh, M. \& McKay, G. 2017. Adsorptive removal of arsenic and mercury from aqueous solutions by Eucalyptus leaves. Water Air Soil Pollution. 429: 1-27.

Bashardoost, R., Vahabzadeh, F., Shokrollahzadeh, S. \& Ali Reza, M. 2010. Sorption performance of live and heat-inactivated loofa-immobilized Phanerochaete chrysosporium in mercury removal from aqueous solution. Iran Journal of Chemical Engineering. 29(4): 7989.

Cabral, L., Giovanella, P., Kerlleman, A., Gianello; C., Menezes Bento, F., \& Oliveira Camargo, F.A. 2014. Impact of selected anions and metals on the growth and in vitro removal of methylmercury by Pseudomonas putida V1. International Biodeterioration \& Biodegradation. 91: 29-36.

Caviedes Rubio, D.I., Muñoz Calderón, R.A., Perdomo Gualtero, A., Rodríguez Acosta, D. \& Sandoval Rojas, I.J. 2015. Tratamientos para la Remoción de Metales Pesados Comúnmente Presentes en Aguas Residuales Industriales. Una Revisión. Revista Ingeniería y Región. 13(1): 73-90.

Cervantes, C., Campos, J., Devars, J.S., Gutiérrez, F., Loza, H., Torres, J.C. \& Moreno, R. 2001. Interactions of chromium with microorganisms and plants. FEMS Microbiology Review. 25: 335-347.

Chaves, M.R.M., Valssaraj, K.T., DeLaune, R.D., Gambrell, R.P. \& Buchler, P.M. 2011. Mercury uptake by biogenic silica modified with L-cysteine. Environmental Technology. 32(14):1615-1625. 
Das, S.K., Das, A. \& Guha, A. 2007. A Study on the Adsorption Mechanism of Mercury on Aspergillus versicolor Biomass. Environmental Science and Technology. 41: 8281-8287.

Duygu Ozsoy, H. 2010. Biosorptive removal of $\mathrm{Hg}(\mathrm{II})$ ions by Rhizopus oligosporus produced from corn-processing wastewater. African Journal of Biotechnology. 9(51): 87838790 .

Giangrosso, G., Cammilleri, G., Macaluso, A.,Vella, A., D’Orazio, N., Graci, S., Lo Dico, G.M. \& Galvano, F., Giangrosso, M. \& Ferrantelli, V. 2016. Hair mercury levels detection in fishermen from Sicily (Italy) by ICP-MS method after microwave-assisted digestion. Bioinorganic Chemistry and Applications Volume 2016, Article ID 5408014, 5 pages.

Hoque, E. \& Johannes Fritscher, J. 2016. A new mercury-accumulating Mucor hiemalis strain EH8 from cold sulfidic spring water biofilms. Microbiology Open. 5(5): 763-781.

Karunasagar, D., Arunachalam, J., 1, Rashmi, K., Naveena, J., Latha, L. \& Maruthi Mohan, P. 2003. Biosorption of inorganic and methyl mercury by a biosorbent from Aspergillus niger. World Journal of Microbiology \& Biotechnology 19: 291-295, 2003.

Koushalshahi, M.B., Issazadeh, K., Tehranifard, A., Khoshkholgh Pahlaviani, M.R. \& Massiha, A. 2012. Isolation of $\mathrm{Hg}$ and $\mathrm{Cu}$ resistant Streptomyces from marine sediments in different regions of the Caspian Sea. African Journal of Microbiology Research. 6(18): 4048-4052.

Leura Vicencio, A.K., Carrizales Yañez, L. \& Razo Soto, I. 2017. Mercury pollution assessment of mining wastes and soils from former silver amalgamation area in NorthCentral Mexico. Revista Internacional de Contaminación Ambiental. 33(4): 655-669.

López Martínez, R., Méndez Tovar, L.J., Hernández Hernández, F. \& Castañón Olivares, R. (2004). Micología Médica. Procedimientos para el Diagnóstico de Laboratorio. Ed. Trillas. México. $2^{\mathrm{a}}$. Ed.

Mahbub, K.R., Kannan Krishnan, K., Megharaja, M. \& Naidua, R. 2016. Bioremediation potential of a highly mercury resistant bacteria strain Sphingobium SA2 isolated from contaminated soil. Chemosphere 144: 330-337.

Martínez Juárez, V.M., Cárdenas-González, J.F., Torre Bouscoulet, M.E. \& Acosta Rodríguez, I. 2012. Biosorption of mercury (II) from aqueous solutions onto fungal biomass. Bioinorganic Chemistry and Applications Volume 2012, Article ID 156190, pp. 1-5. doi:10.1155/2012/156190. ISSN: 15653633.

Nava Ruíz, C. \& Méndez Armenta, M. 2011. Efectos neurotóxicos de metales pesados (cadmio, plomo, arsénico y talio). Archivo de Neurociencias Mexicanas. 16 (3): 140-147. Norma Oficial Mexicana NOM-127-SSA1-1994, Salud ambiental. Agua para uso y consumo humano. Límites permisibles de calidad y tratamientos a que debe someterse el agua para su potabilización. 
Santos, E.E., Cárdenas, J.F., Torre, M.E., Martínez, V.M., Rodríguez, A. \& Acosta, I. 2017. Bioadsorción de arsénico (III) en solución acuosa por la biomasa modificada de Aspergillus niger. Avances en Ciencias e Ingeniería. 8(2): 1-10.

Shekhawata, A., Kahua, S., Saravananb, D. \& Ravin Jugadea, R. 2017. Removal of Cd(II) and $\mathrm{Hg}$ (II) from effluents by ionic solid impregnated chitosan. International Journal of Biological Macromolecules. 104: 1556-1568.

Srivastava S. \& Anil Dwivedi K. 2015. Biological Wastes the Tool for Biosorption of Arsenic. Journal of Bioremediation \& Biodegradation. 7; 323. doi:10.4172/21556199.1000323.

Stefanescu, R, Butnariu, A.E., Zamfirache, M.M., Surleva, A., Ciobanui, C.I., Pintilie, O. \& Drochioiu. G. 2017. Yeast-based microbiological decontamination of heavy metals contaminated soils of Tarnita. Carpathian Journal of Earth and Environmental Sciences. 12 (1): $153-159$.

Tejada-Tovar, C., Villabona-Ortiz, A. \& Garcés-Jaraba, L. 2015. Adsorción de metales pesados en aguas residuales usando materiales de origen biológico. Tecno Lógicas. 18(34): 109-123.

Wang, X., Zhang, D., Qian, H., Liang, Y., Pan, X., \& Gadd, G.M. 2018. Interactions between biogenic selenium nanoparticles and goethite colloids and consequence for remediation of elemental mercury contaminated groundwater. Science of the Total Environment. 613-614: 672-678.

Yalcinkaya, Y., Arica, Y.M., Soysal, L., Den_Izl, A., Genc, I.O. \& Bectas, S. 2002. Cadmium and mercury uptake by immobilized Pleurotus sapidus. Turk Journal of Chemical. 26: 441-452. 